\title{
Two Kings of Redonda: M. P. Shiel and John Gawsworth
}

\section{J O N W Y N NE-TYSON}

It may not be obvious to most readers what Eden Phillpotts, Arthur Ransome, Frank Swinnerton, and Dylan Thomas have in common with Lawrence and Gerald Durrell, Dorothy Sayers, Rebecca West, Roy Campbell, and Henry Miller; or Martin Secker, Victor Gollancz, Alfred A. Knopf, Stephen Potter, J. B. Priestley, and A. F. Tschiffely with Carl Van Vechten, E. H. W. Meyerstein, Edgar Jepson, John Heath-Stubbs, Herbert Palmer, Derek Patmore, J. C. Trewin, and Arthur Machen.

Books apart, very little. Their one certain bond is loyalty to a fellow writer, as a result of which they became members of a literary aristocracy whose origins lie in the last century. (Confirming their appointment as dukes, duchesses, and lesser nobility, I have by me three "State Papers" imposingly printed on eighteenth-century paper and signed in 1947, 1949, and 1951 by G. S. Fraser and Iain Fletcher in their capacities of Grand and Acting Grand Chamberlains of the Realm of Redonda.)

Before all this gets out of hand we must go back to 1865 and the Leeward Islands of the Caribbean.

In that year Matthew Dowdy Shiell, an Irish trader claiming descent from the ancient kings, was sailing past Redonda to his home on the larger island of Montserrat whose lush valleys, hot sulphureous soufrieres and black-sand shores lay 15 miles to the sou'sou'-east. His spirits were high because the free-slave lady of his heart, after presenting him with nine dusky daughters, had at last answered his prayers by producing a son.

But first, Redonda. Named by Columbus in 1493, the island is less than a mile long and a third as wide. Trusting boobies breed on its lonely slopes with carefree abandon; wild goats with trailing beards browse on its sparse vegetation; if humans lived below its wind- 
swept volcanic crags they might be fortunate enough to meet the engaging burrowing owl.

You can see Redonda on a clear day (as most are in that nearidyllic climate) from Montserrat and the more distant heights of Antigua and Nevis; but as landing is almost impossible, and the sole approach to the island's plateau extremely dangerous, the flora and fauna are little disturbed by our rapacious species. For most, the distant view is best, for Redonda is a dramatic thrust of harsh rock, rising nearly a thousand feet out of the warm blue sea, its sheer western cliffs an impregnable home for countless birds.

It was small wonder that father Shiell, looking at Redonda from the deck of his schooner, should have had an idea. A nineteenthcentury Irish trader saddled with nine fuliginous daughters is a doubtful candidate for acknowledged monarchial status. Perhaps with an eye to the wheeling seabirds' discernible deposits of guano in the island's crevices, he then and there decided to annex the great rock as his own unchallenged kingdom. The boobies had got there first, of course, but their trusting, placid natures fitted them more for the role of subjects than competitors.

But uneasy lies ... Fifteen years later, worried by thoughts of succession, Matthew Dowdy took his son Matthew Phipps back to Redonda to have him crowned king by the then Bishop of Antigua in a correctly conducted ceremony of consecration (or so the story goes; just where the officiating cleric came in the church's hierarchy, and how much solemnity was observed, is open to conjecture).

By then, so that its plentiful phosphates could be mined, Redonda had been more officially annexed and declared a dependency of Antigua, but as annexation is after all only a matter of the size of one's gunboat, young Shiell's father did not allow so trifling a detail to spoil a joyous occasion.

The young king, already a student at Harrison College in Barbados, was at the age of 20 sent to King's College, London, going on to teach mathematics in a Derbyshire school, to toy with medicine at Bart's, and to work as an interpreter, before finally deciding on the career of a writer.

For as anyone whose "bible" is Bleiler's famous checklist ${ }^{1}$ will know, M. P. Shiel (he dropped the final $l$ ) became a fantasy writer

1 Everett F. Bleiler, ed., The Checklist of Fantastic Literature; A Bibliography of Fantasy, Weird, and Science Fiction Books Published in the English Language (Chicago: Shasta Publishers, 1948). Reprinted in 1972 and later revised and enlarged under the title The Checklist of Science-Fiction and Supernatural Fiction (Glen Rock, N.J.: Firebell Books, 1978). 


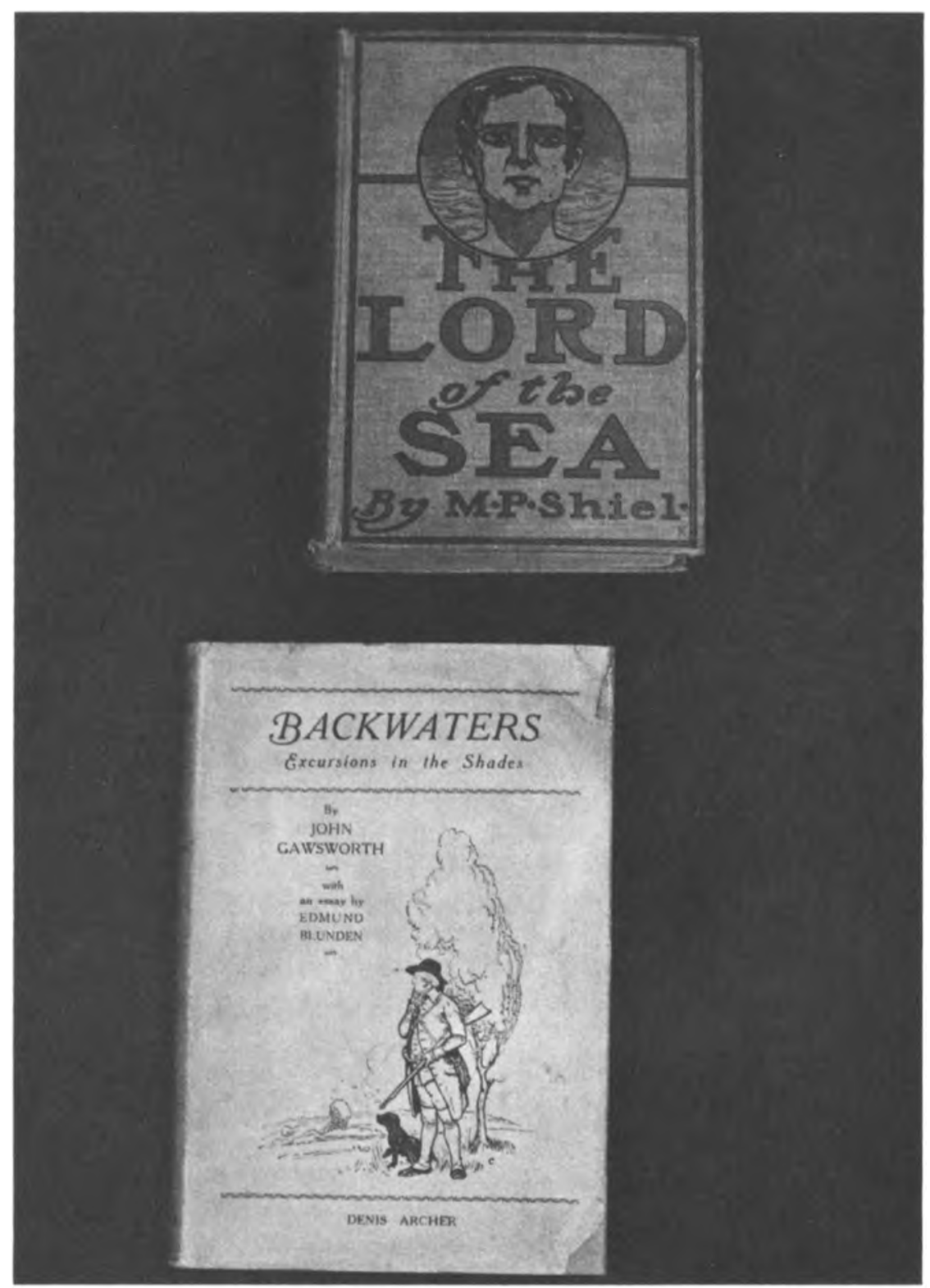

Top: First English edition of a novel by M. P. Shiel, published in London by Grant Richards in 1901. From a copy in The University of Iowa Libraries.

Bottom: John Gawsworth's Backwaters (London: Denis Archer, 1932) provides, along with other pieces, a series of letters between Leigh Hunt and his friend Charles Ollier. From a copy in the Blunden Collection, The University of Iowa Ltbraries. 
with a passionate if not universal following. His first published book, Prince Zaleski (1895), was (as might be expected) decorated by Aubrey Beardsley and issued by John Lane in London and by Roberts Bros. of Boston. For some years Shiel's output was as steady as it was varied. Before the nineteenth century was over, Prince Zaleski had been followed by The Rajah's Sapphire (1896), in collaboration with W. T. Stead; Shapes in the Fire (1896), six short stories; The Yellow Danger (1898); Contraband of War (1899); and Cold Steel (1899).

Helped, perhaps, by his mulatto good looks, young Shiel had not been slow to get to know several of the literary figures of the fin de siècle. If it is churlish to suggest that whom you know can be as important as what or how you write, his connections would seem to have done him no harm; nor did his marriage to Lina, a beautiful young Parisian Spaniard and the Laura of his novel Cold Steel.

Perhaps Shiel's best-known book is The Purple Cloud (1901), which ran into many editions and was adapted in 1959 for the film The World, the Flesh, and the Devil. Later novels and short stories included The Lord of the Sea (1901), The Last Miracle (1906), The Isle of Lies (1909), The Pale Ape (1911), and Dr. Krasinski's Secret (1929). Most of Shiel's books have been reprinted several times, and his work is currently enjoying a considerable vogue.

However, with publication in 1980 of the second and greatly augmented edition of A. Reynolds Morse's 858-page bibliography, The Works of M. P. Shiel Updated (now in two volumes and including Shiel's "About Myself," the fully illustrated account of the 1978 and 1979 "Quest for Redonda" and much other material), far more information is now available than can be offered in a short article. $^{2}$

Opinions of Shiel's merits as a writer are as varied as his prejudices and enthusiasms. Walpole called him a "blazing genius"; J. B. Priestley dubbed The Purple Cloud "a masterpiece"; Wells, Bennett, Rebecca West, and Edward Shanks praised his work highly. His present admirers are no less adulatory. Indeed, Shiel is in danger of becoming a cult figure. In the second-hand book field many of his works fetch breath-depriving prices; much of his work has been pirated and widely translated.

That Shiel's style was florid, grotesque, at times preposterous,

2 Albert Reynolds Morse, The Works of M. P. Shiel Updated: A Study in Bibliography, second ed., 2 vols. [Cleveland]: Reynolds Morse Foundation, 1980. 
only his most unbalanced admirers would deny. More probably, they acknowledge the fact with pride. He has been compared with Poe, Corvo, and Melville; but his characters are mostly cardboard creatures, symbols rather than human beings, vehicles for often dubious and long-winded disquisitions. For compression and economy of style he had no time. But it is equally undeniable that at best he displayed immense vitality, a vivid imagination, and a talent that for some amounts to genius.

The unevenness of Shiel's work and outlook have prompted a range of reactions from total dismissal to unqualified worship. $\mathrm{He}$ would pursue the irrelevant to the dregs of most readers' patience, and many of his racial and political statements are beyond the progressive stomach of our day. But with the greater knowledge we now have of his unpromising origins, we must wonder at and admire the dogged persistence of a man who overcame so many inherited and temperamental limitations to make his mark in the hidebound world of the late Victorian era.

Shiel died in Sussex in 1947, having appointed as his literary executor and successor to the "throne" of Redonda his indefatigable bibliographer, Terence Fytton Armstrong, better known as the poet and man of letters John Gawsworth.

In his foreword to Shiel's Science, Life, and Literature Gawsworth tells how in 1931, when a 19-year-old publisher's clerk, "imbued with a fanatic literary enthusiasm," he wrote to Shiel, embarking on a collaboration that was to last for 16 years.

Gawsworth had already issued his first pamphlet of verses, and in "Some Notes on My Friend John Gawsworth 1962"3 Lawrence Durrell calls him his first Real Writer-"a professional living by his books." He continues:

I say "living," but the word should have some qualification, for he barely existed on his work, inhabiting an old attic in Denmark Street, with a huge dormer window and a rotting wooden floor through which seeped the noise of jazz being played by Percival Mackay's band rehearsing downstairs. I was a complete literary novice and a provincial and the meeting was an important one for me, for in John I found someone who burned with a hard gem-like flame-the very thing I wished to do myself; moreover his gem-like burnings were then sufficiently good to merit the attention of real publishers, while my post-Imagist maunderings and occasional derivative sonnets did not.

3 Lawrence Durrell, Spirit of Place: Letters and Essays on Travel, ed. Alan G. Thomas (New York: E. P. Dutton \& Co., 1969), pp. 17-23. 
Durrell, banished by his mother from Bournemouth ("You can be as Bohemian as you like but not in the house. I think you had better go somewhere where it doesn't show so much"), and accompanied by his beautiful young wife, met Gawsworth for the first time at 3:00 a.m. in the Windmill Cafe in London's West End. John was correcting galley proofs "with a heavy self-commiserating air" and drinking black coffee. Durrell had never before seen galleys: the vie Boheme had been found at last. When he learned that John had actually met such giants as Yeats, Hardy, and Wyndham Lewis, his night was made. The three of them returned to John's gas-lit attic where the Durrells were shown an already impressive collection of those first editions, manuscripts, poets' letters, and literary curiosities by whose sale, with diminishing replacements, he supported himself in alcohol and life's lesser expenses year after year in the postwar decades.

It was a sad, wasteful decline. The man whom Durrell had found "in physique of medium height and somewhat pale and lean," with "a broken nose which gave his face a touch of Villonesque foxiness ... eyes brown and bright ... his sense of humour unimpaired by his literary privations," never succeeded in reestablishing himself in the London literary scene when his army stint was over. The Faberians were in control. Gawsworth managed to get Sidgwick and Jackson to publish his collected poems, but it was a swan song rather than a launching pad. He was not willing to truckle with the modern movement. He was romantic, a Georgian, which doubtless accounted for most of his literary admirers being elderly; towards some he showed generosity and loyalty. On the debit side, he could be tediously persistent, exploitative, and bellicose. His royalism, as Durrell remarks, "also chimed with his literary attitude; even when he was very poor he would rise at dawn and pad down to Covent Garden to buy a large white rose to place upon the statue of Charles I" on the anniversary of the king's execution.

Such gestures irritated more people than they charmed. But few who knew him would have denied that his passion for literature was the most genuine part of a nature capable of deviousness and childlike pettiness. The fact that he had been made a freeman of the city of London in 1935, had been elected to the Royal Society of Literature in 1938, and awarded the Benson Medal in 1939, may have been tangible acknowledgment of his precocity, but it made him few friends. It was the old story of a man who had peaked too soon. Acclaim, if not material success, had come too early. There had been an insufficiently decent interval of struggle. 
His Georgian inclinations were as good an excuse as any for being written off, and his increasing alcoholic frenzies, slovenly dress and habits, and physical deterioration invited contempt and neglect.

A few kept faithful: those perhaps foolish enough to regret the waste and to feel that maybe something, somehow, some day "could be done about John." Sober, even at the end of his life he could still impress with his knowledge, his perceptions, even with faint flashes of that old sense of humor.

"His memory for bibliography was simply amazing," Durrell wrote:

... Had he cared to be a bookseller he would now be the greatest one in England ... he was a walking literary calendar of London, and seemed to have a gigantic mental file of anniversaries tucked away in his brain. Thus we would drink to Dr. Johnson on appropriate days in Lambs Conduit Street, or eat a chop in the memory of Sheridan or Goldsmith whenever the requisite moment dawned. I can hardly think of London even today without remembering these walks, those visits to remote chop houses or pubs; he always knew where to knock up a glass of Burgundy ("Machen came here every day") in Fleet Street, or a glass of Canary ("Try this: Ouida's favourite tipple") in Cheapside. He was as much of a Londoner as Lamb or Leigh Hunt or Hazlitt-and indeed he never tired of talking about them and their London, and comparing it to the rushing and grubby city in whose rainswept streets he walked, determined to carry on the great tradition they had left us.

But the story of Gawsworth waits to be told more fully by whoever may write an impartial book about the literary figures of the thirties. ${ }^{4}$ Gawsworth-or the undried lake of Burgundy within himhad made too many enemies. Elephants and the literati run trunk to trunk when it comes to bearing grudges.

It was Gawsworth who created most of Redonda's "nobility," though he never set eyes. on his kingdom. On his death in 1970 , mourned by few, his work as forgotten as Shiel's had been in 1947, he left as his and Shiel's literary executor, and Redonda's third and most reluctant monarch, a writer and publisher whose profile is by choice somewhat low.

4 Gawsworth is presently represented at The University of Iowa Libraries by nearly one hundred cataloged printed items, one hundred and fifty manuscripts, and approximately three hundred items of correspondence. Among his correspondents are Warwick Deeping, Lawrence Durrell, Clifford Dyment, Eleanor Farjeon, David Garnett, Monk Gibbon, W. W. Jacobs, M. R. James, Pamela Hansford Johnson, Shane Leslie, Rose Macaulay, Phyllis Megroz, Oliver Onions, Arthur Quiller-Couch, Ernest Rhys, and E. H. Visiak. 
The legend of Redonda is, and should remain, a pleasing and eccentric fairy tale; a piece of literary mythology to be taken with salt, romantic sighs, appropriate perplexity, some amusement, but without great seriousness. It is, after all, a fantasy that has already passed into history and even into some history books; a fact which qualifies it to be seen as both bunk and inspiration. ${ }^{5}$

5 Listings for both Shiel and Gawsworth can be found in Vol. IV, 1900-1950, of The New Cambridge Bibliography of English Literature, ed. J. R. Willison. Much fuller information about the legend of Redonda is to be found in the Morse bibliography, cited above in note 2 . 